Please do not remove this page

RMIT

UNIVERSITY

\title{
Cul catalyzed sulfonylation of organozinc reagents with sulfonyl halides
}

Fu, Ying; Zhu, Wenbo; Zhao, Xingling; Hugel, Helmut; Wu, Zhouqiang; Su, Yuhu; Du, Zhengyin https://researchrepository.rmit.edu.au/esploro/outputs/9921859998201341/filesAndLinks?institution=61RMIT_INST\&\&index=null

Fu, Y., Zhu, W., Zhao, X., Hugel, H., Wu, Z., Su, Y., Du, Z., Huang, D., \& Hu, Y. (2014). Cul catalyzed sulfonylation of organozinc reagents with sulfonyl halides. Organic and Biomolecular Chemistry, 12(25), 4295-4299. https://doi.org/10.1039/c4ob00638k

Document Version: Accepted Manuscript

Published Version: https://doi.org/10.1039/c4ob00638k

Repository homepage: https://researchrepository.rmit.edu.au

(C) The authors ; This journal is (c) The Royal Society of Chemistry 2014

Downloaded On 2023/04/26 23:11:21 +1000 
Thank you for downloading this document from the RMIT Research Repository.

The RMIT Research Repository is an open access database showcasing the research outputs of RMIT University researchers.

RMIT Research Repository: http://researchbank.rmit.edu.au/

\section{Citation:}

Fu, Y, Zhu, W, Zhao, X, Hugel, H, Wu, Z, Su, Y, Du, Z, Huang, D and Hu, Y 2014, 'Cul catalyzed sulfonylation of organozinc reagents with sulfonyl halides', Organic and Biomolecular Chemistry, vol. 12, no. 25, pp. 4295-4299.

See this record in the RMIT Research Repository at:

https://researchbank.rmit.edu.au/view/rmit:28798

Version: Accepted Manuscript

Copyright Statement: @ The authors ; This journal is ( $)$ The Royal Society of Chemistry 2014

Link to Published Version:

http://dx.doi.org/10.1039/c4ob00638k

PLEASE DO NOT REMOVE THIS PAGE 


\title{
CuI Catalyzed Sulfonylation of Organozinc Reagents with Sulfonyl halides
}

\author{
Ying Fu, ${ }^{a}{ }^{a}$ Wenbo Zhu, ${ }^{a}$ Xingling Zhao, ${ }^{a}$ Helmut Hügel, ${ }^{b}$ Zhouqiang Wu, ${ }^{a}$ Yuhu Su, ${ }^{a}$ Zhengyin Du, ${ }^{a}$ \\ Danfeng Huang ${ }^{a}$ and Yulai $\mathrm{Hu}^{a}$
}

\author{
seceived (in XXX, XXX) Xth XXXXXXXXX 20XX, Accepted Xth XXXXXXXXX 20XX \\ DOI: $10.1039 / \mathbf{b 0 0 0 0 0 0 x}$
}

In this study, a facile $\mathrm{CuI}$ catalyzed synthesis of sulfones involving a nucleophilic addition of functionalized organozinc reagents to organic sulfonyl chlorides is realized. This 10 reaction proceeds efficiently at room temperature, giving rise to variously functional substituted sulfones, generally in moderate to high yields. The method provides a novel, simple, and promising strategy for functionalized sulfone synthesis in the research field of sulfur chemistry.

${ }_{15}$ Sulfones are ubiquitous bioactive molecules ${ }^{1}$ and are widely applied as important intermediates in organic synthesis ${ }^{2}$ and polymeric compounds. ${ }^{3}$ The Friedel-Crafts (FC) sulfonylation of arenes by organic sulfonyl halides or sulfonic anhydrides, ${ }^{4}$ and the nucleophilic substitution reaction of organic halides with 20 thiols, followed by oxidation of the corresponding sulfides ${ }^{5}$ are the two most commonly used synthetic approaches for the preparation of aryl and alkyl sulfones. However, these methods generally involve drawbacks as the FC sulfonylation is limited to arenes bearing electron-donating substituents and always leads to

25 formation of isomeric mixtures of products. For sulfide oxidation, the use of odoriferous and hazardous thiols is a major concern. Thus alternative procedures, especially those using organic sulphinates as the sulfonylation precursor, the use of aryl halides, ${ }^{6}$ arylboronic acids, ${ }^{7}$ diaryliodonium salts, ${ }^{8}$ heterocycles ${ }^{9}$ 30 or olefins $^{10}$ as substrates have been developed in recent years. However, drawbacks such as the use of expensive noble metal complexes, limited substrate availability, use of air- or moisturesensitive reagents, incompatibility with various functional groups etc. are some disadvantages of these procedures. Therefore, it is 35 imperative that a simple, convenient and generally applicable protocol for both aryl and alkyl sulfones synthesis is found.

The nucleophilic addition of Grignard reagents or organolithium reagents to sulfonyl halides ${ }^{11}$ or esters ${ }^{12}$ are straightforward, albeit limited to practical sulfone synthesis 40 owing to the strong nucleophilicity of these organometallic reagents and the weak $\mathrm{C}-\mathrm{S}$ bond of sulfonyl halides and sulfones. Various kinds of by-products are obtained with the sulfone products, and the mechanisms of these side reactions are still unconfirmed. Nevertheless, C-C formed products instead of C-S 45 cross coupling sulfone products were frequently obtained using transition metal catalysis. ${ }^{13}$

Organozinc reagents are mild and functional group tolerant organometallic reagents that are widely used as surrogates for Grignard reagents or organolithium reagents. ${ }^{14}$ Previously ${ }_{50}$ Vogel's group reported that the palladium catalysed reaction of organozinc reagents with sulfonyl chloride occurred via a desulfinylative Negishi-type cross-coupling reaction to give alkanes in low to moderate yield. ${ }^{13 \mathrm{~b}}$ However, From our experiences concerning the reactivity and applications of 55 organometallic reagents ${ }^{15}$ in organic synthesis, and a brief report on the synthesis of allyllic sulfones via a zinc Barbier type reaction of allylic bromides with sulfonyl chloride, ${ }^{16}$ we were enticed to explore the possibility of C-S bond construction by the reaction of organozinc reagents with sulfonyl chlorides with mild 60 reaction conditions (Scheme 1).

a) Prior work

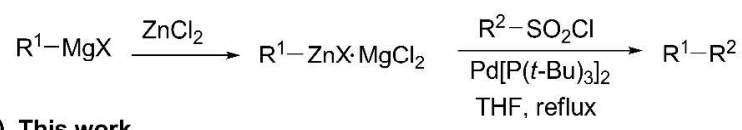

b) This work

$$
\mathrm{R}^{1}-\mathrm{X} \underset{\mathrm{ZnCl}}{\stackrel{\mathrm{Mg}}{\mathrm{Zn}}} \mathrm{R}^{1}-\mathrm{ZnX} \cdot \mathrm{MgCl}_{2} \underset{\begin{array}{c}
\text { Cul, TMEDA } \\
0^{\circ} \mathrm{C} \text { to } \mathrm{RT}
\end{array}}{\stackrel{\mathrm{R}^{2}-\mathrm{SO}_{2} \mathrm{Cl}}{\longrightarrow}} \mathrm{R}^{1}-\stackrel{\mathrm{II}}{\mathrm{S}}-\mathrm{R}^{2}
$$

Scheme 1 Comparison of this work and a previous report reaction of organozinc reagents with sulfonyl chlorides. (a) $\mathrm{Pd}\left[\mathrm{P}(t-\mathrm{Bu})_{3}\right]_{2}$ catalyzed dusulfitative $\mathrm{C}-\mathrm{C}$ cross-coupling coupling reaction selective towards 65 biphenyls. (b) CuI-catalyzed C-S cross-coupling reactions selective towards sulfones (this work).

Initially we prepared phenylzinc bromide (1a), by stirring $\mathrm{PhBr}$ with magnesium turnings in the presence of one equiv of $\mathrm{ZnCl}_{2}$, as the nucleophile (Table 1). ${ }^{17}$ Examination of the 70 products of the reaction of (1a) with $p$-toluenesulfonyl chloride (2a) at room temperature for $24 \mathrm{~h}$, detected only a trace amount of sulfone (3a) with nearly all of $\mathbf{2 a}$ being recovered (entry 1). Lewis acids are known to be powerful additives in promoting nucleophilic addition reaction of organometallic reagents towards 75 carbonyl or imine compounds. However, in this reaction system, no appreciable effect was observed after the addition of one equivalent of $\mathrm{LiCl}$ (entry 2). ${ }^{18}$ Other Lewis acids such as TMSCl, $\mathrm{BF}_{3} \cdot \mathrm{Et}_{2} \mathrm{O}, \mathrm{ZnCl}_{2}$ all failed in promoting this reaction. The phenomenon that Lewis acids did not enhance the electrophilicity 80 of sulfonyl chlorides implies that the electron density of the sulfonyl oxygens is too low to effectively complex with Lewis acids. 
On the other hand, Lewis bases showed some efficiency in this reaction system. As shown in Table 1, after the addition of 2 equiv of $\mathrm{Et}_{3} \mathrm{~N}, 3 \mathbf{a}$ was obtained in $23 \%$ yield. A slightly higher yield of 3a (36\%) was obtained when 2 equiv of TMEDA was 5 added (entry 4). Transition metal complexes also showed some efficacy in these reactions. As illustrated in Table 1, the addition of $5 \%$ equivalent of $\mathrm{Ni}(\mathrm{acac})_{2}$ slightly enhanced the reaction rate after 12 hours, sulfone 3a was obtained in $42 \%$ isolated yield (entry 5). $\mathrm{Ni}\left(\mathrm{PPh}_{3}\right)_{2} \mathrm{Cl}_{2}$ and $\mathrm{Ni}(\mathrm{OAc})_{2}$ showed similar beneficial 10 effects on this reaction and sulfone 3a was obtained in similar yields (entries 6 and 7). Cuprous salts are attractive catalysts in promoting the nucleophilicity of organozinc reagents. ${ }^{19}$ Gratifyingly, these catalysts showed great efficiency on the nucleophilic addition of the organozinc reagent 1a towards 15 sulfonyl chloride 2a. Of the cuprous salts studied, $\mathrm{CuI}(1 \mathrm{mmol})$ was shown to be the most efficient, as after half an hour all of the sulfonyl chloride 2a was consumed (entry 11).

Table 1. Optimization of the reaction conditions ${ }^{a}$

\begin{tabular}{ccccc}
20 & & & & \\
\hline
\end{tabular}

${ }^{a}$ Reaction conditions: $p$-toluenesufonyl chloride $\mathbf{2 a}(5 \mathrm{mmol})$ was treated with phenylzinc reagent $\mathbf{1 a}(10 \mathrm{mmol})$ in THF $(15 \mathrm{~mL})$ under nitrogen. ${ }^{b}$ Isolated yields. ${ }^{c} 0.5 \mathrm{mmol}$ of catalyst was added. ${ }^{d} 1.0 \mathrm{mmol}$ of catalyst was added. ${ }^{e}$ Reaction carried out under extremely strict moisture and air 25 free condition.

Initially, we are concerned that Vogel's C-C cross-coupling products would be predominant, since these have been extensively studied in the cross-coupling reactions with various organometallic reagents ${ }^{13}$ including boronic acids, ${ }^{20}$ 30 organostannane ${ }^{21}$ and alkenes. ${ }^{22}$ However, our GC-MS product analysis confirmed their absence. In fact the main challenge we encountered in our Lewis base and cuprous salt catalyzed sulfonylation of organozinc reagents was not the low nucleophilicity of organozinc reagents 1a, nor the low 35 electrophilicity of sulfonyl chlorides $\mathbf{2 a}$ or the desulfonylation of organic sulfonyl chlorides, but the high sensitivity of the sulfonyl chlorides and organozinc reqagents towards oxygen and moisture in the reaction environment when THF was dried without nitrogen protection, the dried THF is air saturated; after drying 40 glassware in an oven, trace amounts of moisture and air are absorbed on the silica surface; sulfonyl chlorides can quickly absorb moisture from the environment. All the trace amounts of moisture and air accumulated in the reaction flask resulted in nearly one-third of the sulfonyl chloride forming byproducts as 45 denoted in Scheme 2. The phenomenon that large amounts of sulfonyl chloride is consumed by zinc phenoxide and zinc hydroxide species is in sharp contrast to the reactions of organometallic reagents with carbonyl compounds (aldehydes and ketones) as in which trace amounts of moisture and oxygen so do did react with organometallic reagents immediately, however, the resulting alkoxide and hydroxide do not irreversibly attack carbonyl compounds. In order to compare the nucleophlicities of phenyl and phenoxide in organozinc reagents, diphenylzinc (6) derived from phenyl magnesium bromide and half an equivalent 55 of $\mathrm{ZnBr}_{2}$ was converted to phenylzinc phenoxide (7) and was then added to a solution of $p$-toluenesulfonyl chloride (2a) with the same reaction conditions. After half an hour's stirring, phenyl 4-methylbenzenesulfonate (5) was obtained in quantitative yield whereas the desired sulfone (3a) was undetected. With the 60 exclusion of moisture/air, the modified reaction conditions increased the yield of sulfone (3a) to $91 \%$ (Table 1, entry 12).

a)

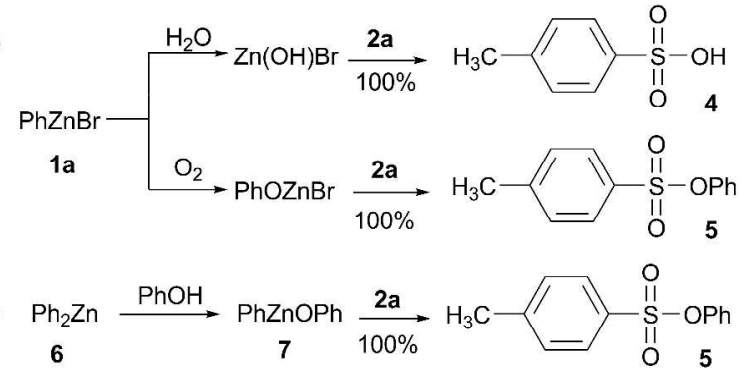

Scheme 2 Influence of oxygen and moisture in the reactions of sulfonyl halides with organozinc reagents: (a) sulfonyl chlorides are highly oxygen 65 and moisture sensitive reagents. (b) the phenoxide nucleophilic substitution reaction with sulfonyl chloride.

With the optimized reaction conditions in hand, the scope and limitation of various functionalized sulfonyl chlorides were then examined using phenylzinc bromide 1a as the nucleophile. As 70 summarized in Table 2, aryl sulfonyl chlorides substituted with electron-donating or electron-withdrawing groups were successfully converted into the corresponding diaryl sulfones (3ah) in good to excellent yields. Generally, aryl sulfonyl chlorides bearing electron-donating groups in the benzene rings reacted 75 slightly slower than those sulfonyl chlorides bearing electronwithdrawing substituents, albeit the yields are generally higher. Notably, alkyl sulfonyl chlorides can also be used in this reaction system, as shown in Table 2, reaction of phenylzinc bromide 1a with methyl sulfonyl chloride gave the phenyl methyl sulfone $\mathbf{3} \mathbf{j}$ 80 in $68 \%$ yield. However, highly sterically hindered aromatic sulfonyl chlorides, such as 2-fluoro-6-(trifluoromethyl)benzene1-sulfonyl chloride and 2-(2,2-difluoroethoxy)-6(trifluoromethyl)benzene-1-sulfonyl chloride are especially unstable in these reaction systems and decomposed immediately ${ }_{85}$ after $1 \mathrm{a}$ was added, even when the reaction was cooled to $-78^{\circ} \mathrm{C}$ (3k and 31). A prominent advantage of this methodology is the compatibility of functional groups including amide, halogenes $(\mathrm{Cl}, \mathrm{Br}$ and $\mathrm{F})$ and nitro $(\mathbf{3 e}, \mathbf{3 e}, \mathbf{3 f} \sim \mathbf{h})$. 
Table 2. Reaction Results of phenylzinc bromide with sulphonyl chlorides ${ }^{a, b}$

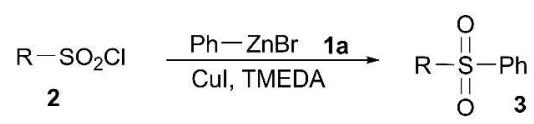

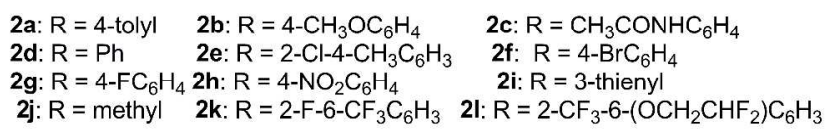

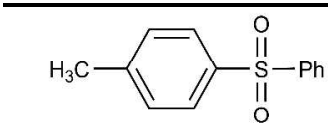

3a: $90 \%$<smiles>CCNc1ccc(S(=O)(=O)c2ccccc2)cc1</smiles>

3c: $92 \%$<smiles>Cc1ccc(S(=O)(=O)c2ccccc2)c(Cl)c1</smiles>

3e: $82 \%$<smiles>O=S(=O)(c1ccccc1)c1ccccc1</smiles>

3g: $77 \%$<smiles>O=S(=O)(c1ccccc1)c1ccsc1</smiles>

3i: $66 \%$<smiles>O=S(=O)(c1ccccc1)c1c(F)cccc1C(F)(F)F</smiles>

3k: trace

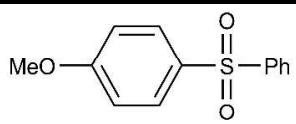

3b: $87 \%$

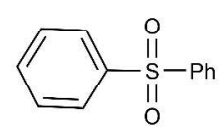

3d: $87 \%$<smiles>O=S(=O)(c1ccccc1)c1ccc(Br)cc1</smiles>

3f: $86 \%$

$\mathrm{O}_{2} \mathrm{~N}$

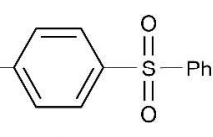

3h: $72 \%$<smiles>CS(=O)(=O)c1ccccc1</smiles>

3j: $68 \%$

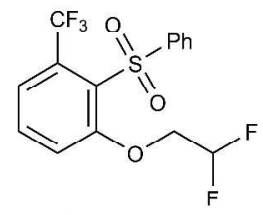

31: $0 \%$
${ }^{a}$ Reaction conditions: $p$-toluenesulfonyl chloride $\mathbf{2 a}(5 \mathrm{mmol})$ was treated 5 with phenylzinc reagent 1 a $(10 \mathrm{mmol})$ in THF $(15 \mathrm{~mL})$ under nitrogen. ${ }^{b}$ Isolated yields.

Encouraged by these successful results on sulfonyl chlorides, we subsequently set out to explore the scope of organozinc reagents. As demonstrated in Table 3, functionalized organozinc 10 reagents having chloro- $(\mathbf{8 g}, 9 \mathbf{d}$ and $9 \mathrm{e})$, bromo- $(\mathbf{8 a} \sim \mathbf{8 d})$, fluoro-(8e, $8 \mathbf{f}$ and $8 \mathbf{h}$ ) trifluoromethyl-(8g and $\mathbf{8 h}$ ), and cyano groups (9f) could be employed in these reaction systems obtaining good to high yields of sulfones. Different type of aryl and heteroarylzinc reagents, such as $\alpha$ - and $\beta$-naphthylzinc 15 bromide, 4-biphenylzinc bromide and 3-thienylzinc bromide all reacted with aromatic sulfonyl chlorides to give the diaryl sulfones in good to excellent yields. Sterically hindered aromatic zinc reagents, such as 2-chloro-6-(trifluoromethyl)phenylzinc(II) chloride, prepared by in situ transformation of corresponding 20 lithium reagent with one equivalent of $\mathrm{ZnCl}_{2}$, did not react with sulfonyl chloride $\mathbf{2 a}$. (8e)

Table 3. Reaction results of functionalied organozinc reagents with sulphonyl chlorides ${ }^{a}$

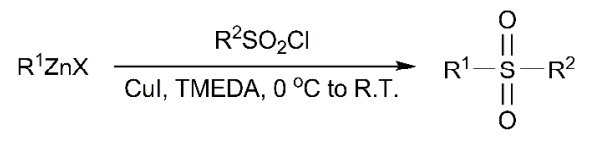

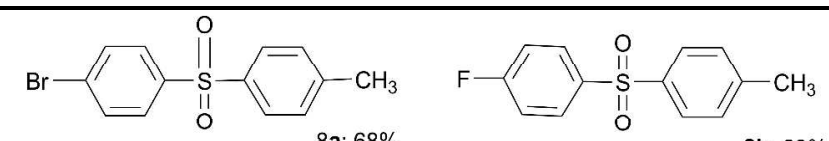<smiles>Cc1ccc(S(=O)(=O)c2ccc(S(=O)(=O)c3ccc(Br)cc3)cc2)cc1</smiles>

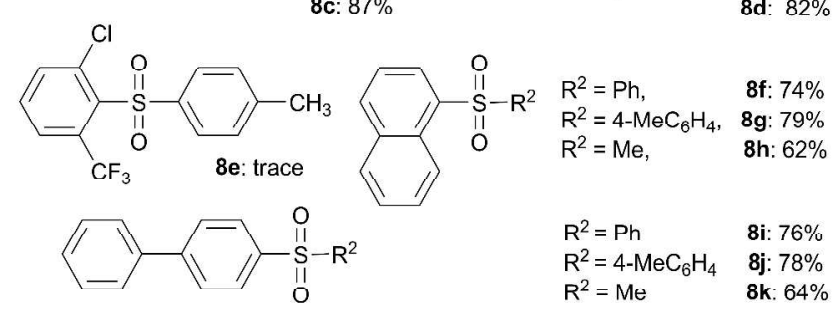
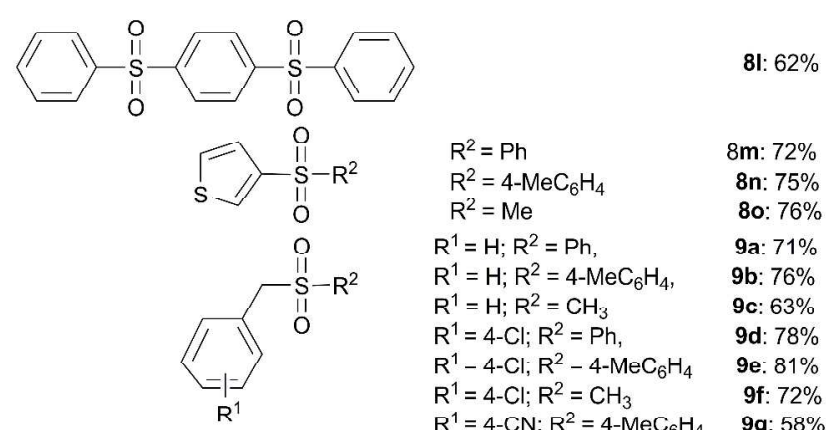

$$
\begin{array}{rr}
\mathrm{R}^{2}=\mathrm{Ph} & \text { 8m: } 72 \% \\
\mathrm{R}^{2}=4-\mathrm{MeC}_{6} \mathrm{H}_{4} & \text { 8n: } 75 \% \\
\mathrm{R}^{2}=\mathrm{Me} & \text { 8o: } 76 \% \\
\mathrm{R}^{1}=\mathrm{H} ; \mathrm{R}^{2}=\mathrm{Ph}, & 9 \text { a: } 71 \% \\
\mathrm{R}^{1}=\mathrm{H} ; \mathrm{R}^{2}=4-\mathrm{MeC}_{6} \mathrm{H}_{4}, & \text { 9b: } 76 \% \\
\mathrm{R}^{1}=\mathrm{H} ; \mathrm{R}^{2}=\mathrm{CH}_{3} & \text { 9c: } 63 \% \\
\mathrm{R}^{1}=4-\mathrm{Cl} ; \mathrm{R}^{2}=\mathrm{Ph}, & 9 \text { d: } 78 \% \\
\mathrm{R}^{1}-4-\mathrm{Cl}, \mathrm{R}^{2}-4-\mathrm{MeC}_{6} \mathrm{H}_{4} & \text { 9e. } 81 \% \\
\mathrm{R}^{1}=4-\mathrm{Cl} ; \mathrm{R}^{2}=\mathrm{CH}_{3} & \text { 9f: } 72 \% \\
\mathrm{R}^{1}=4-\mathrm{CN} ; \mathrm{R}^{2}=4-\mathrm{MeC}_{6} \mathrm{H}_{4} & \text { 9g: } 58 \% \\
\mathrm{R}^{1}=4-\mathrm{Bu}^{t} ; \mathrm{R}^{2}=4-\mathrm{NO}_{2} \mathrm{C}_{6} \mathrm{H}_{4} & \text { 9h: } 63 \%
\end{array}
$$

${ }^{a}$ Reaction conditions: organic sulfonyl chloride $(5 \mathrm{mmol})$ was treated with organozinc reagent $(10 \mathrm{mmol})$ in THF $(15 \mathrm{~mL})$ under nitrogen. ${ }^{b}$ Isolated yields.

Benzyl sulfones have significant functions in organic 30 synthesis $^{23}$ and biochemistry. ${ }^{24}$ These compounds are normally synthesized from corresponding benzyl chloride via sulfinate ${ }^{25}$ or sulfide in multiple steps. In our protocol, benzylic zinc reagents, easily prepared from benzylic halides with zinc metal, reacted smoothly with sulfonyl chlorides to give the corresponding 35 sulfones in moderate to high yields $(\mathbf{9 a} \sim \mathbf{9 h})$.

Attempts to introduce aliphatic zinc halide reagents into this protocol failed, presumably owing to the weak nucleophilicity and strong alkalinity of these organozinc reagents. Neither aromatic nor aliphatic sulfonyl chlorides gave the corresponding 40 sulfones in acceptable yields. Gratifyingly, diorganozinc reagents showed good efficiency in these reaction systems. As shown in Scheme 3, primary and secondary dialkyl zinc reagents (dioctylZn and diisopropylZn), readily prepared via the in situ reaction of $n$-octyl and isopropyl bromide, magnesium turnings 45 and 0.5 equivalent of $\mathrm{ZnCl}_{2}$, reacted readily to give the corresponding sulfones in good yields. 


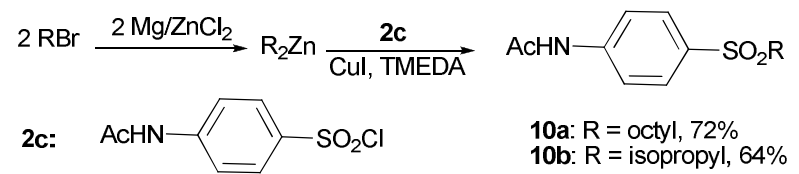

Scheme 3 Reaction of dialkyl zinc reagents with sulfonic chloride

\section{Conclusions}

In summary, we have developed a new efficient and general 5 approach for a $\mathrm{CuI}$ catalyzed synthesis of alkyl, aryl and heteroaryl sulfones bearing various kinds functional groups. The sluggish reactivity of organozinc reagents towards sulfonyl chlorides can be efficiently improved by the addition of $\mathrm{CuI}$ and bidentate chelate ligand, TMEDA. This practical procedure 10 considerably extends the reactivity scope of organozinc reagents. In particular, the direct reaction with sulfonyl chlorides allows the expeditious preparation of various sulfones in high yields.

\section{Acknowledgements}

The authors are grateful for financial support from the National ${ }_{15}$ Natural Science Foundation of China (No. 21262030 and 20962017) and the Natural Science Foundation of Gansu Province, China (No. 1107RJZA263).

\section{Notes and references}

${ }^{a}$ College of Chemistry and Chemical Engineering, Northwest Normal 20 University, Lanzhou, Gansu 730070, P. R. China. Fax: +8609317970989; E-mail: fuying@iccas.ac.cn

${ }^{b}$ Health Innovations Research Institute \& School of Applied Sciences, RMIT University, Melbourne, VIC 3001 Australia.

$\dagger$ Electronic Supplementary Information (ESI) available: [details of any 25 supplementary information available should be included here]. See DOI: $10.1039 / \mathrm{b} 000000 \mathrm{x} /$

\$ Footnotes should appear here. These might include comments relevant to but not central to the matter under discussion, limited experimental and spectral data, and crystallographic data.

301 For recent reviews, see: (a) N. Isoherranen, J. D. Lutz, S. P. Chung, H. Hachad, R. H. Levy and I. Ragueneau-Majlessi, Chem. Res. Toxicol., 2012, 25, 2285; (b) S. S.Bharate and S. B. Bharate, ACS Chem. Neurosci. 2012, 3, 248.

2 N. S. Simpkins, Sulfones in Organic Synthesis, Pergamon Press, Oxford, 1993

3 M. A. Hickner, H. Ghassemi, Y. S. Kim, B. R. Einsla and J. E. McGrath, Chem. Rev. 2004, 104, 4587.

4 (a) Z. Wu, H. Song, X. Cui, C. Pi, W. Du and Y. Wu, Org. Lett., 2013, 15, 1270; (b) S. Répichet, C. Le Roux, P. Hernandez and

40 J. Dubac, J. Org. Chem. 1999, 64, 6479; (c) J. Marquié, A. Laporterie and J. Dubac, J. Org. Chem. 2001, 66, 421.

5. (a) K. Schank, In The Chemistry of Sulfones and Sulfoxides; S. Patai, Z. Rappoport, C. J. M. Stirling, Eds.; Wiley: New York, 1988; Chapter 7; (b) G. Yuan, J. Zheng, X. Gao, X. Li, L. Huang, H. Chen

45 and H. Jiang, Chem. Commun. 2012, 48, 7513; (c) M. Rahimizadeh, G. Rajabzadeh, S. M. Khatami, H. Eshghi and A. Shiri, J. Mol. Catal. A: Chem. 2010, 323, 59; (d) A. Rostami and J. Akradi, Tetrahedron Lett. 2010, 51, 3501.

6 (a) M. Baidya, S. Kobayashi and H. Mayr, J. Am. Chem. Soc. 2010,

$50 \quad$ 132, 4796; (b) K. M. Maloney, J. T. Kuethe and K. Linn, Org. Lett. 2011, 13, 102-105; (c) W. Zhu and D. Ma, J. Org. Chem. 2005, 70, 2696; (d) S. Cacchi, G. Fabrizi, A. Goggiamani, L. M. Parisi and R. Bernini, J. Org. Chem. 2004, 69, 5608; (e) J. M. Baskin and Z.-Y. Wang, Org. Lett. 2002, 4, 4423; (f) S. Cacchi, G. Fabrizi, A.

55 Goggiamani and L. M. Parisi, Org. Lett. 2002, 4, 4719-4721; (g) C. Beaulieu, D. Guay, Z. Wang and D. A. Evans, Tetrahedron Lett.
2004, 45, 3233; (h) M. Bian, F. Xu and C. Ma, Synthesis, 2007, 2951.

7 (a) A. Kar, I. A. Sayyed, W. F. Lo, H. M. Kaiser, M. Beller and M. K. 60 Tse, Org. Lett. 2007, 9, 3405; (b) M. L. Kantam, B. Neelima, B. Sreedhar and R. Chakravarti, Synlett, 2008, 1455; (c) B. P. Bandgar, S. V. Bettigeri and J. Phopase, Org. Lett. 2004, 6, 2105.

8 (a) N. Umierski and G. Manolikakes, Org. Lett, 2013, 15, 188; (b) S. C. Cullen, S. Shekhar and N. K. Nere, J. Org. Chem., 2013, 78, 6512194.

9 (a) F. Xiao, H. Chen, H. Xie, S. Chen, L. Yang and G.-J. Deng, Org. Lett. 2014, 16, 50; (b) P. Katrun, C. Mueangkaew, M. Pohmakotr, V. Reutrakul, T. Jaipetch, D. Soorukram and C. Kuhakarn, J. Org. Chem. 2014, 79, 1778; (c) S. Liang, R.-Y. Zhang, L.-Y. Xi, S.-Y. Chen and X.-Q. Yu, J. Org. Chem., 2013, 78, 11874.

10 X. Zhou, J. Luo, J. Liu, S. Peng and G.-J. Deng, Org. Lett. 2011, 13, 1432.

11 (a) H. Fukuda, F. J. Frank and W. E. Truce, J. Org. Chem. 1963, 28, 1420; (b) H. Gilman and R. E. Fothergill, J. Am. Chem. Soc. 1929,

75 51, 3501. (c) Y. Shirota, T. Nagai and N. Tokura, Tetrahedron, 1967, 23, 639; (d) Y. Shirota, T. Nagai and N. Tokura, Tetrahedron, 1969, $\mathbf{2 5}, 3193$.

12 (a) H. Gilman, N. J. Beaber and C. H. Myers, J. Am. Chem. Soc. 1925, 47, 2047; (b) W. H. Baarschers, Can. J. Chem. 1976, 54, 3056.

8013 (a) C. M. Rao Volla and P. Vogel, Angew. Chem. Int. Ed. 2008, 47, 1305; (b) S. R. Dubbaka and P. Vogel, Tetrahedron Lett. 2006, 47, 3345. (c) C. M. Rao Volla, S. R. Dubbaka and P. Vogel, Tetrahedron 2009, 65, 504. (d) E. Erdik and F. Eroglu, Synth. React. Inorg. Met.Org. Chem. 2000, 30, 955.

8514 For reviews on organozinc chemistry, see: (a) Z. Rappoport and I. Marek, The Chemistry of Organozinc Compounds: R-Zn, Wiley, Chichester, UK, 2006; (b) P. Knochel and P. Jones, Organozinc Reagents: A Practical Approach, Oxford University Press, Oxford, 1999; (c) E. Erdik, Organozinc Reagents in Organic Synthesis, CRC,

90 New York, 1996; (d) P. Knochel and R. D. Singer, Chem. Rev., 1993, 93, 2117.

15 (a) Y. Fu, Y. Liu, Y. Chen, H. M. Hügel, M. Wang, D. Huang and Y. Hu, Org. Biomol. Chem. 2012, 10, 7669. (b) Y. Fu, Y. Yang, H. M. Hügel, Z. Du, K. Wang, D. Huang and Y. Hu, Org. Biomol. Chem., 2013, 11, 4429; (c) Y. Fu, X. Hu, Y. Chen, Y. Yang, H. Hou and Y. $\mathrm{Hu}$, Synthesis 2012, 44, 1030. (d) J.-X. Wang, Y. Fu and Y. L. Hu, Angew. Chem. Int. Ed. 2002, 41, 2757. (e) Y. Fu, J.-X. Wang, K. Wang and Y. Hu, Tetrahedron 2008, 64, 11124.

16 P. Sun, L. Wang and Y. Zhang, Tetrahedron Lett. 1997, 38, 5549.

10017 A. Metzger, S. Bernhardt, G. Manolikakes and Paul Knochel, Angew. Chem. Int. Ed. 2010, 49, 4665.

18 (a) C. J. Rohbogner, S. H. Wunderlich, G. C. Clososki, P. Knochel, Eur. J.Org. Chem. 2009, 1781. (b) A. Krasovskiy, P. Knochel, Angew. Chem., Int. Ed. 2004, 43, 3333.

10519 P. Knochel, N. Millot, A. L. Rodriguez and C. E. Tucker, in Organic Reactions, 2004, 417.

20 (a) S. R. Dubbaka and P. Vogel, Org Lett. 2004, 6, 95; (b) S. Zhang, X. Zeng, Z. Wei, D. Zhao, T. Kang, W. Zhang, M. Yan and M. Luo, Synlett 2006, 1891.

11021 S. R. Dubbaka and P. Vogel, J. Am. Chem. Soc. 2003, 125, 15292.

22 (a) S. R. Dubbaka and P. Vogel, Chem. Eur. J. 2005, 11, 2633; (b) L. Cao, K. Weidner and P. Renaud, Adv. Synth. Catal. 2011, 353, 3467; (c) S. R. Dubbaka, D. Zhao, Z. Fei, C. M. Rao Volla, P. J. Dyson and P. Vogel, Synlett 2006, 3155.

11523 (a) D. A. Alonso, C. Nájera, M. Varea, Tetrahedron Lett. 2004, 45, 573; (b) D. A. Alonso, M. Fuensanta, C. Nájera, M. Varea, J. Org. Chem. 2005, 70, 6404.

24 M. Lu, S. Merali, R. Gordon, J. Jiang, Y. Li, J. Mandeli, X. Duan, J. Fallon, J. F. Holland, Genes \& Cancer, 2011, 2, 985.

12025 (a) F. W. Lewis, T. C. McCabe, D. H. Grayson, Tetrahedron, 2011, 67, 7517 . 